\title{
Duality of B Cell-CXCL13 Axis in Tumor Immunology
}

\author{
Angel J. Rubio ${ }^{1}$, Tyrone Porter ${ }^{2}$ and Xuemei Zhong ${ }^{3 *}$ \\ ${ }^{1}$ Department of Pharmacology and Experimental Therapeutics, Boston University, Boston, MA, United States, ${ }^{2}$ Department \\ of Biomedical Engineering, University of Texas Austin, Austin, TX, United States, ${ }^{3}$ Hematology and Medical Oncology \\ Section, Department of Medicine, Boston University School of Medicine, Boston, MA, United States
}

\section{OPEN ACCESS}

Edited by:

Jose A. Garcia-Sanz, Consejo Superior de Investigaciones Cientificas (CSIC), Spain

Reviewed by: Olga Sizova,

University of Texas MD Anderson Cancer Center, United States Jose Joaquin Merino, Universidad Complutense de Madrid, Spain

*Correspondence: Xuemei Zhong xuemei.zhong03@gmail.com

Specialty section:

This article was submitted to Cancer Immunity and Immunotherapy, a section of the journal Frontiers in Immunology

Received: 17 December 2019 Accepted: 20 August 2020 Published: 21 October 2020

Citation:

Rubio AJ, Porter T and Zhong X (2020) Duality of B Cell-CXCL13 Axis in Tumor Immunology.

Front. Immunol. 11:521110. doi: 10.3389/fimmu.2020.521110
Tumor immunity is a rapidly evolving area of research consisting of many possible permutations of immune cell tumor interactions that are dependent upon cell type, tumor type, and stage in tumor progression. At the same time, the majority of cancer immunotherapies have been focused on modulating the $T$ cell-mediated antitumor immune response and have largely ignored the potential utility that B cells possess with respect to tumor immunity. Therefore, this motivated an exploration into the role that B cells and their accompanying chemokine, CXCL13, play in tumor immunity across multiple tumor types. Both B cells and CXCL13 possess dualistic impacts on tumor progression and tumor immunity which is furthered detail in this review. Specifically, various B cells subtypes are able to suppress or enhance several important immunological functions. Paradoxically, CXCL13 has been shown to drive several pro-growth and invasive signaling pathways across multiple tumor types, while also, correlating with improved survival and immune cell tumor localization in other tumor types. Potential tools for better elucidating the mechanisms by which B cells and CXCL13 impact the antitumor immune response are also discussed. In addition, multiples strategies are proposed for modulating the B cell-CXCL13 axis for cancer immunotherapies.

Keywords: B cell, CXCL13, tumor immunology, tumor infiltrated immune cells, tumor immune cell interaction

\section{INTRODUCTION}

Recent advances in cancer immunotherapies have highlighted the potential of employing the immune system to impede tumor progression. A major focus has been on employing the T cellmediated antitumor immune response (1). However, given the complexity of the immune system and known interplay between $\mathrm{T}$ cells and $\mathrm{B}$ cells, the role of $\mathrm{B}$ cells with respect to antitumor immunity should not be overlooked. For instance, B cells have been shown to modulate $\mathrm{T}$ cell differentiation and mediate $\mathrm{T}$ cell response to tumor antigens $(2,3)$. Also, B cells possess a diverse array of immunological functions ranging from antibody and cytokine production to phagocytosis of which contribution to tumor immunity is largely unknown (4-8).

Recent studies have explored utilizing antigen presenting cells (APCs) such as dendritic cells (DCs) for cancer immunotherapy (9). B cells also operate as APCs and can be expanded ex vivo, so they may too serve as a viable option for cancer immunotherapy (10). Additionally, a significant number of B cells are found in tumors and tumor-draining lymph nodes (TDLNs), localized sites of high immunological activity near tumors (11). However, their exact role remains unclear as contradictory studies have shown that they can be drivers of tumor progression through 
facilitating immunosuppressive microenvironments or contributors to the antitumor immune response through antigen presentation and $\mathrm{T}$ cell activation $(10,11)$. Therefore, more studies are necessary to elucidate B cells' role in tumor immunity.

Equally important, chemokines dictate proper immune cell trafficking and are being pursued for cancer immunotherapies (12). With respect to tumor immunity, they are becoming increasingly highlighted for their ability to drive immune cell tumor recruitment and impact the tumor-infiltrating lymphocytes (TILs) population. For example, CXCL13 interacts with the chemokine receptor CXCR5 which is present on B cells and some tumor cells and has been implicated as key modulators of both tumor progression and antitumor immunity (13). Studies have shown that CXCL13 can drive tumor growth and invasion through PI3K/AKT signaling or contribute to an enhanced antitumor immune response via increased tumor immune localization $(14,15)$. Therefore, further inquiry is required to determine its role in tumor immunity. In this review we will delve into the literature of B cells and CXCL13 and attempt to provide the most updated analysis of their roles in tumor immunity. Additionally, we will postulate on their ability to be leveraged for innovative cancer immunotherapies.

\section{B CELLS SUBTYPES AND FUNCTIONS}

The contribution of $\mathrm{B}$ cells in tumor immunity remains controversial. However, there is consensus on their importance for generating antibodies which bind to specific antigen epitopes and label them for degradation or targeting (16). B cells function as APCs by utilizing their B cell receptor (BCR) to recognize antigens and are important for presenting foreign and autoantigens to CD4+ T cells (17-19). B cells can regulate immune system homeostasis through the production of cytokines which modulate $\mathrm{T}$ cell differentiation, inflammation, and lymphoid tissue architecture (20).

It is important to define several B cell subtypes to better understand how they may contribute to tumor immunity. For instance, regulatory B cells (Bregs) are important for ensuring proper immunological tolerance and may help combat autoimmunity $(21,22)$. Bregs can express the immunosuppressive cytokines, IL-10, TGF- $\beta$, and IL-35, to impair the activity of DCs and T cells (23). Also, Breg-derived IL-10 is important for promoting regulatory $\mathrm{T}$ cells (Tregs), which further contribute to immune suppression (24). Bregs via increased expression of TGF- $\beta 1$ and IL-10 can induce anergy of CD8+ $\mathrm{T}$ cells and apoptosis of CD4+ $\mathrm{T}$ cells, respectively $(25,26)$. With this in mind, it is apparent that Bregs act to dampen immune activity which may contribute to a less robust antitumor immune response. However, because they lack an identifying marker, it is challenging to specifically study their intratumoral functions and interactions with other TILs (27).

Furthermore, conventional recirculating B cells (B2 B cells) can be further stratified into follicular (FO) or marginal zone (MZ) B cells (20). Naive FO B cells reside in lymph node follicles where they present antigens to activated $\mathrm{T}$ cells (28). After maturation, they circulate throughout the lymphatic and circulatory system and are the main driver of high-affinity antibody production (29). MZ B cells reside in the spleen MZ where they monitor for blood pathogens utilizing their polyreactive BCRs $(30,31)$. They can respond to antigens without assistance from $\mathrm{T}$ cells and are able to transport antigens to FO $\mathrm{B}$ cells residing in spleen follicles (32).

In contrast, B1 B cells are primarily compartmentalized in the pleural and peritoneal cavities and are hypothesized to be part of innate immune memory (33). They are characterized by their ability to self-renew and constitutively produce natural antibodies (34). These natural antibodies are coded by the germline VDJ sequences and recognize apoptotic cell membranes $(35,36)$. B1 B cells are also able to phagocytose dying mammalian cells (37). Dysregulation of apoptotic cell clearance can lead to necrosis and inflammation, both of which are associated with tumor progression $(38,39)$. Therefore, B1 B cells may help mitigate potential inflammatory responses by recognizing and clearing dying cells. Also, B1 B cells can stimulate T cell expansion via CD80/CD86 and promote differentiation of CD4+ T cells (3). Similar to MZ B2 B cells, B1 B cells are capable of eliciting a T cell-independent response (40). B1 B cells differ from B2 B cells, in that they are larger, have resistance to FAS-induced apoptosis, and possess greater ex vivo survivability (41). Similar to Bregs, human B1 B cells lack a consensus on their identifying surface markers so studying them in the tumor microenvironment remains difficult (42).

\section{EVIDENCE OF B CELLS PROMOTING TUMOR PROGRESSION}

Given the complex nature of B cells in promoting or suppressing immune response, it is important to detail how they can potentially hamper or promote antitumor immunity. For instance, antibodies can lead to the generation of circulating immune complexes (CIC) which have been associated with poor prognosis in pancreatic ductal adenocarcinoma patients (43). These CIC can suppress the immune response of myeloid cells which then provides an additional barrier to a robust antitumor immune response $(44,45)$. In prostate cancer, B cellsecreted lymphotoxin (LT) was shown to drive STAT3 signaling to promote tumor growth (46). In a mouse melanoma and lung cancer model, B cells with activated STAT3 contributed to increased tumor growth through the promotion of angiogenesis (47). Additionally, a study showed that B cells can promote bladder cancer metastasis by increasing ECM (extracellular matrix) remodeling gene expression (48).

Furthermore, Bregs TGF-beta production can drive conversion of $\mathrm{CD} 4+\mathrm{T}$ cells to Tregs leading to inhibition of CD8+ T cells and Natural Killer (NK) cells, both of which are important for limiting tumor growth $(49,50)$. In a mouse breast cancer model, tumor-evoked Bregs (tBregs) promoted transition of resting CD4 $+\mathrm{T}$ cells to Treg cells which correlated with greater metastasis (51). Additionally, tBregs have been shown to elevate myeloid-derived suppressor cells ROS and NO generation leading to $\mathrm{CD} 4+$ and $\mathrm{CD} 8+\mathrm{T}$ cells suppression (52). IL-10 can hamper the production of additional stimulatory 
cytokines leading to decreased responsiveness of CD8+ $\mathrm{T}$ cells, Th1 cells, and NK cells $(53,54)$. B cells may drive tumor progression through promoting expression of various genes that drive tumorigenesis or by weakening the immune response.

\section{B CELLS' ANTITUMOR FUNCTIONS AND PROGNOSTIC VALUE}

In contrast, there is evidence that B cells can be beneficial for enhancing antitumor immunity either directly by interacting with tumor cells or indirectly by assisting additional immune functions. For example, stimulated human $\mathrm{B}$ cells in vitro have demonstrated the ability to induce lysis of melanoma cells through expression of TRAIL/Apo-2L (55). TIL B cells isolated from breast cancer tissues have been reported to express granzyme $\mathrm{B}$ and exhibited in vitro cytotoxic activity toward breast cancer cells (56). An additional study has shown that TDLN B cells utilize FasL to directly interact with mammary cancer cells and induce lysis (57). This suggest that B cells may contribute to antitumor immunity by directly killing cancer cells.

In addition, B cells are capable of generating tumor-specific antibodies and have shown to provide protective benefits against breast cancer $(16,58)$. Additionally, tumor-binding antibodies have been shown to be able to promote tumor cell uptake by DCs (59). Furthermore, in a mouse glioblastoma model, B cell antigen presentation was shown to be essential for $\mathrm{T}$ cellmediated antitumor response (60). The depletion of B cells with anti-CD20 monoclonal antibodies in a melanoma mouse model resulted in hampered $\mathrm{CD} 4+$ and $\mathrm{CD} 8+\mathrm{T}$ cell response (61). Also, activated B cells from cervical cancer patients have been shown to stimulate $\mathrm{T}$ cell-mediated antitumor responses (62).

The presence of TIL B cells in multiple cancer types has shown to be a positive prognostic marker for survival. For example, analysis of colorectal cancer tissue samples demonstrated that high $\mathrm{B}$ cell infiltration was a good indicator for positive clinical outcome (15). A separate study on human colorectal cancer, determined that TIL B cells were associated with improved patient outcome (63). Likewise, in multiple studies analyzing non-small-cell lung carcinoma (NSCLC) samples, high $B$ cell tumor infiltration generally correlated with better clinical outcomes (64-66). Also, analysis of ovarian tumors showed a positive association between $\mathrm{B}$ cell tumor infiltration and patient survival (67).

\section{CXCL13 FUNCTION}

CXCL13 is a 10 kilodalton CXC chemokine that is important for mobilizing B cells. Similar to B cells, CXCL13 has been identified as possessing a dualistic impact on tumor progression. For instance, CXCL13 has been associated with metastasis, while at the same time is associated with greater patient survival $(15,68)$. It is expressed by follicular DCs (FDCs) and helper $\mathrm{T}$ cells and is essential for naive $\mathrm{B}$ cell homing and organization within lymphoid follicles, sites critical for B cellantigen interaction and B cell differentiation (69, 70). Also, CXCL13 drives B cell LT expression which in turn promotes increased CXCL13 levels to generate a positive feedback loop (71). CXCL13 through CXCR5 signaling enhances BCR-triggered B-cell activation by altering cell dynamics to enhance antigen gathering at the $\mathrm{B}$ cell immune synapse (72). With respect to differences among B cell subtypes, B1 B cells express greater CXCR5 than B2 B cells which may important for ensuring that $\mathrm{B} 1 \mathrm{~B}$ cells are recruited and provide localized immunity to the peritoneal cavity (70). This is evidenced in CXCL13-deficient mice which have reduced B1 B cell natural antibody production and response to bacterial antigens in the peritoneum (68). These findings highlight the importance of CXCL13 for regulating B cells.

\section{CXCL13'S ROLE IN DRIVING TUMOR PROGRESSION}

CXCL13 has been found to act on cancer cells and potentially drive tumor progression. The addition of CXCL13 to breast cancer cells in vitro increased expression of matrix metalloproteinase-9 (MMP-9) and genes reasonable for driving the epithelial to mesenchymal transition (EMT) (73). MMP-9 is important for ECM remodeling and invasion of tumor cells through the basement membrane. Additionally, the EMT is a common step in tumor progression for epithelial cell cancers (74). CXCL13 administration to oral squamous cell carcinomas (OSCC) resulted in heightened CXCR5 and MMP-9 expression (75). Similarly, in prostate cancer cell lines, the addition of CXCL13 increased expression of ECM remodeling genes (76). Also, CXCL13 through CXCR5 was shown to promote growth and invasion via the PI3K/AKT pathway in clear cell renal carcinoma (14). In liver cancer, CXCL13 has been shown to activate the pro-growth Wnt/B-catenin signaling pathway (77). Furthermore, CXCL13 may have a specific role in promoting bone metastasis. CXCL13 knockdown resulted in reduced prostate cancer and OSCC bone invasion in mouse models $(75,76)$.

With respect to hematological cancers, specifically, B cell chronic lymphocytic leukemia (B-CLL) and acute lymphocytic leukemia (B-ALL), there is significant evidence that CXCL13 drives pro-growth and survival signaling $(78,79)$. Additionally, increased serum CXCL13 levels were found to be associated with greater risk of B cell non-Hodgkin's lymphoma (NHL) in HIVinfected individuals (80). Given CXCL13's impact on B cells, it is somewhat intuitive that it would exacerbate B cell malignancies. In summary, tumor cells may utilize CXCL13 to promote growth, invasion, and metastasis.

\section{CXCL13'S ROLE IN ENHANCING ANTITUMOR IMMUNITY}

In contrast, CXCL13 may contribute to a greater antitumor immune response through improving immune cell tumor infiltration. For instance, in human breast cancer tumor tissues greater CXCL13 expression was linked with increased $\mathrm{T}$ cell and B cell tumor recruitment (81). Furthermore, among colorectal cancer patients, increased intratumoral CXCL13 correlated with 
greater $\mathrm{T}$ cell and $\mathrm{B}$ cell tumor infiltration and prolonged patient survival (15). CXCL13 administration into the colonic submucosa of mice with colorectal cancer resulted in decreased tumor growth (15). Additionally, in patients with HER2+ breast cancer increased CXCL13 correlated with better survival (82). High expression of CXCL13 among triple negative breast cancer (TNBC) patients corresponded with better outcomes (83). Likewise, analysis of genome-wide cDNA expression of tumor samples from ovarian cancer patients revealed that high CXCL13 correlated with better prognosis (84). CXCL13 may hinder tumor progression by increasing the number of immune cells at the tumor site which is evidenced by its correlation with greater prognosis and survival in multiple tumor types. The complex impact of CXCL13 on tumor immunity is summarized in Table 1.

TABLE 1 | CXCL13 impact across different types of cancer.

\begin{tabular}{|c|c|c|}
\hline $\begin{array}{l}\text { Cancer } \\
\text { type }\end{array}$ & Pro-tumor & Antitumor \\
\hline $\begin{array}{l}\text { Breast } \\
\text { cancer }\end{array}$ & $\begin{array}{l}\text { In vitro addition to } \\
\text { MDA-MB- } 231 \text { cells } \\
\text { increases MMP expression } \\
\text { Model: Mouse cancer } \\
\text { cells (68) }\end{array}$ & $\begin{array}{l}\text { Correlated with greater } \\
\text { survival and immune tumor } \\
\text { infiltration } \\
\text { Model: ex vivo analysis of } \\
\text { human breast cancer tissue } \\
(81) \\
\text { HER2+/TNBC: Correlated } \\
\text { with better prognosis } \\
\text { Model: Human clinical data } \\
(82,83)\end{array}$ \\
\hline $\begin{array}{l}\text { Genitourinary } \\
\text { cancers }\end{array}$ & $\begin{array}{l}\text { Clear cell renal carcinoma: } \\
\text { Promotes PI3K/AKT } \\
\text { signaling (CXCR5+) } \\
\text { Model: human tissue } \\
\text { analysis (14) Prostate } \\
\text { cancer: Enhances ECM } \\
\text { remodeling and bone } \\
\text { metastasis (CXCR5+) } \\
\text { Model: human engineered } \\
\text { cell lines and xenograft } \\
\text { mouse model (76) }\end{array}$ & $\begin{array}{l}\text { Ovarian cancer: Correlated } \\
\text { with better prognosis } \\
\text { Model: Human healthy and } \\
\text { cancerous tissue cDNA } \\
\text { expression data (84) }\end{array}$ \\
\hline $\begin{array}{l}\text { Colorectal } \\
\text { cancer }\end{array}$ & N/A & $\begin{array}{l}\text { Correlated with improved } \\
\text { survival } \\
\text { Model: Human clinical data } \\
\text { (15) }\end{array}$ \\
\hline OSCC & $\begin{array}{l}\text { Increases MMP expression } \\
\text { and bone } \\
\text { invasion (CXCR5+) } \\
\text { Model: Human-derived } \\
\text { OSCCs cells and xenograft } \\
\text { mouse model }(75)\end{array}$ & $\mathrm{N} / \mathrm{A}$ \\
\hline $\begin{array}{l}\text { Liver } \\
\text { cancer }\end{array}$ & $\begin{array}{l}\text { Liver Cancer: Drives Wnt } \\
\text { signaling (CXCR5+) } \\
\text { Model: in vitro analysis of } \\
\text { human samples ( } 77)\end{array}$ & N/A \\
\hline Leukemia & $\begin{array}{l}\text { B-CLL and B-ALL: } \\
\text { Promotes } \\
\text { apoptosis resistance } \\
\text { Model: in vitro analysis of } \\
\text { human samples }(78,79)\end{array}$ & $\mathrm{N} / \mathrm{A}$ \\
\hline
\end{tabular}

\section{POTENTIAL OF B CELLS AND CXCL13 IN CANCER IMMUNOTHERAPY}

B cells as well as CXCL13 play multifunctional roles in tumor immunity. Careful modulation of each may prove to be effective for bolstering existing cancer immunotherapies or for designing novel stand-alone treatments. For example, B cells have multiple characteristics such as ability to be readily expanded ex vivo, produce antibodies and present antigens to $\mathrm{T}$ cells which make them a viable option for adoptive cell transfer therapy (10). B cells isolated from TDLNs of mice inoculated with breast cancer cells were activated ex vivo and administered to mice with breast cancer (85). The activated B cells were able to induce tumor-specific $\mathrm{T}$ cell immunity and prevent lung metastases. Also, the activated $\mathrm{B}$ cells in combination with activated $\mathrm{T}$ cells resulted in tumor regression demonstrating the therapeutic potential of using B cells. An additional study showed that stimulated B cells could be employed for cross-presenting tumorspecific antigens to T cells (86). In this study, activated B cells loaded with tumor antigen were capable of impeding tumor growth, demonstrating that B cells can potentially be a standalone treatment option. Alternatively, inhibiting Breg cell activity may be beneficial for targeting tumors with immunosuppressive microenvironments. This would be most useful in tumors with high Breg infiltration.

Additionally, CXCL13 may be utilized to improve the antitumor immune response by increasing B cell localization to tumor site. In humans, CXCL13 has been shown to increase B cell tumor infiltration and correlate with prolonged survival in multiple tumor types (82-84). In mouse colorectal cancer studies, direct CXCL13 administration was effective for impeding tumor growth (15). Also, CXCL13 can initiate a positive feedback loop for B cell activation so it may useful to deliver CXCL13 into the tumor to enhance TIL B cell antitumor functions (71). Additionally, CXCL13 can be utilized to selectively target B cells. CpG-oligodeoxynucleotides (ODNs) conjugated to CXCL13 for $\mathrm{B}$ cell-specific delivery resulted in enhanced B cells activation of CD8+ T cells and reduced lung metastasis (87). CXCL13 can be similarly employed to deliver inhibitory agents to Bregs to combat intratumoral immune suppression. Also, CXCL13 can potentially be used in conjunction with $\mathrm{B}$ cell-based immunotherapies to improve B cell tumor localization and result in greater efficacy. In contrast, for CXCR5+ tumors, antibody blockade of CXCL13 may be a useful strategy for preventing CXCL13-driven tumor growth and invasion. For instance, administration of anti-CXCL13 to MDA-MB-231 cells in vitro resulted in apoptosis (88).

\section{DISCUSSION}

Although B cells' role in tumor immunity is quite complex, it is apparent that they are important modulators as they are capable of both hindering or promoting antitumor immunity. Specifically, Breg activity may drive an immunosuppressive tumor microenvironment by suppressing $\mathrm{T}$ cell and DC activity $(21,23)$. In contrast, B1 B cells may contribute to a more 
effective antitumor immune response by enhancing $\mathrm{T}$ cellmediated immune response (3). However, for both B cell subtypes there is a lack a consensus on their human surface markers and, therefore, they are difficult to study within the context of cancer $(21,42)$.

Additional tools are needed to accurately analyze B cell subtypes within tumor microenvironments. In addition to surface markers, functional ex vivo assays on isolated TIL-B cell subtypes may help further define roles. For instance, isolated TIL$\mathrm{B}$ cells could be co-cultured with CD4+ and CD8+ T cells and monitored using the modulation of $\mathrm{T}$ cells as a readout. If specific TIL-B cells are identified as stimulating $\mathrm{T}$ cell activity, then they can be furthered genotyped to identify gene expression patterns that reflect the change in cell status and functions during the immune response. Similarly, CXCL13's role in tumor immunity is contradictory $(82,88)$. Analyzing the amount of intratumoral CXCL13 after tumors have been excised does not clearly decipher

\section{REFERENCES}

1. Bethune, MT, Joglekar AV. Personalized T cell-mediated cancer immunotherapy: progress and challenges. Curr Opin Biotechnol. (2017) 48:142-52. doi: 10.1016/j.copbio.2017.03.024

2. Popi AF, Longo-Maugéri IM, Mariano M. An overview of B-1 cells as antigenpresenting cells. Front Immunol. (2016) 7:138. doi: 10.3389/fimmu.2016.00138

3. Restifo NP, Dudley ME, Rosenberg SA. Adoptive immunotherapy for cancer: harnessing the T cell response. Nat Rev Immunol. (2012) 12:26981. doi: 10.1038/nri3191

4. Atif SM, Gibbings SL, Redente EF, Camp FA, Torres RM, Kedl RM, et al. Immune surveillance by natural $\operatorname{IgM}$ is required for early neoantigen recognition and initiation of adaptive immunity. Am J Respir Cell Mol Biol. (2018) 59:580-91. doi: 10.1165/rcmb.2018-0159OC

5. Tsiantoulas D, Diehl CJ, Witztum JL, Binder CJ. B cells and humoral immunity in atherosclerosis. Circ Res. (2014) 114:174356. doi: 10.1161/CIRCRESAHA.113.301145

6. Elkon, KB, Silverman GJ. Naturally occurring autoantibodies to apoptotic cells. In: Naturally Occurring Antibodies (NAbs), New York, NY: Springer. (2012). p. 14-26. doi: 10.1007/978-1-4614-3461-0_2

7. Lei X, Liu C, Azadzoi K, Li C, Lu F, Xiang A, et al. A novel IgM-H-Ficolin complement pathway to attack allogenic cancer cells in vitro. Sci Rep. (2015) 5:7824. doi: 10.1038/srep07824

8. Garaud S, Zayakin P, Buisseret L, Rulle U, Silina K, de Wind A, et al. Antigen specificity and clinical significance of IgG and IgA autoantibodies produced in situ by tumor-infiltrating B cells in breast cancer. Front Immunol. (2018) 9:2660. doi: 10.3389/fimmu.2018.02660

9. Le Gall CM, Weiden J, Eggermont LJ, Figdor CG. Dendritic cells in cancer immunotherapy. Nat Mater. (2018) 17:4745. doi: 10.1038/s41563-018-0093-6

10. Li Y, Yuan S, Deng J. Harnessing B cells for cancer immunotherapy. J Med Oncl Ther. (2016) 1:8-13. doi: 10.35841/medical-oncology.1.1.8-13

11. Yuen GJ, Demissie E, Pillai S. B lymphocytes and cancer: a love-hate relationship. Trends Cancer. (2016) 2:74757. doi: 10.1016/j.trecan.2016.10.010

12. Tokunaga R, Zhang W, Naseem M, Puccini A, Berger MD, Soni S, et al. CXCL9, CXCL10, CXCL11/CXCR3 axis for immune activationa target for novel cancer therapy. Cancer Treat Rev. (2018) 63:407. doi: 10.1016/j.ctrv.2017.11.007

13. Tan P, Shi M, Lai L, Tang Z, Xie N, Xu H, et al. Regulative role of the CXCL13CXCR5 axis in the tumor microenvironment. Precision Clin Med. (2018) 1:49-56. doi: 10.1093/pcmedi/pby006

14. Zheng Z, Cai Y, Chen H, Chen Z, Zhu D, Zhong Q, et al. CXCL13/CXCR5 axis predicts poor prognosis and promotes progression through if CXCL13 is a driver or responder to tumor progression. Instead, new tools that enable real-time tracking of CXCL13 expression during tumor progression are necessary to more accurately address this inquiry. Ultimately, B cells and CXCL13 have great therapeutic potential for cancer treatments. However, researchers must be cautious as both must be considered with respect to tumor type and CXCR5 tumor expression. It is pertinent that information on the $B$ cell tumor population and tumorimmune microenvironment is known before pursuing this type of immunotherapy.

\section{AUTHOR CONTRIBUTIONS}

AR wrote the initial draft of the manuscript. XZ and TP contributed to the editing and revising of this work. All authors contributed to the article and approved the submitted version.

PI3K/AKT/mTOR pathway in clear cell renal cell carcinoma. Front Oncol. (2019) 8:682. doi: 10.3389/fonc.2018.00682

15. Bindea G, Mlecnik B, Tosolini M, Kirilovsky A, Waldner M, Obenauf AC, et al. Spatiotemporal dynamics of intratumoral immune cells reveal the immune landscape in human cancer. Immunity. (2013) 39:78295. doi: 10.1016/j.immuni.2013.10.003

16. Schlößer HA, Thelen M, Lechner A, Wennhold K, Garcia-Marquez MA, Rothschild SI, et al. B cells in esophago-gastric adenocarcinoma are highly differentiated, organize in tertiary lymphoid structures and produce tumor-specific antibodies. Oncoimmunology. (2019) 8:e1512458. doi: 10.1080/2162402X.2018.1512458

17. Hughes, CE, Benson RA, Bedaj M, Maffia P. Antigen-presenting cells and antigen presentation in tertiary lymphoid organs. Front Immunol. (2016) 7:481. doi: 10.3389/fimmu.2016.00481

18. Opata MM, Hollifield ML, Lund FE, Randall TD, Dunn R, Garvy BA, et al. B lymphocytes are required during the early priming of CD4+ $\mathrm{T}$ cells for clearance of Pneumocystis infection in mice. J Immunol. (2015) 195:61120. doi: 10.4049/jimmunol.1500112

19. Choi SC, Morel L. B cell contribution of the CD4+ T cell inflammatory phenotypes in systemic lupus erythematosus. Autoimmunity. (2017) 50:3741. doi: 10.1080/08916934.2017.1280028

20. LeBien, Tucker W., Tedder TF. B lymphocytes: how they develop and function. Blood. (2008) 112:1570-80. doi: 10.1182/blood-2008-02-078071

21. Rosser EC, Mauri C. Regulatory B cells: origin, phenotype, and function. Immunity. (2015) 42:607-12. doi: 10.1016/j.immuni.2015.04.005

22. Park MK, Jung YO, Lee S-Y, Lee S-H, Heo YJ, Kim EK, et al. Amelioration of autoimmune arthritis by adoptive transfer of Foxp3-expressing regulatory B cells is associated with the Treg/Th17 cell balance. J Transl Med. (2016) 14:191. doi: 10.1186/s12967-016-0980-z

23. Berthelot JM, Jamin C, Amrouche K, Le Goff B, Maugars Y, Youinou P. Regulatory B cells play a key role in immune system balance. Joint Bone Spine. (2013) 80:18-22. doi: 10.1016/j.jbspin.2012.04.010

24. Lu Y, Liu F, Li C, Chen Y, Weng D, Chen J. IL-10-producing B cells suppress effector $\mathrm{T}$ cells activation and promote regulatory $\mathrm{T}$ cells in crystalline silica-induced inflammatory response in vitro. Mediat Inflamm. (2017) 2017:8415094. doi: 10.1155/2017/8415094

25. Boldison J, Da Rosa LC, Davies J, Wen L, Wong FS. Dendritic cells license regulatory $\mathrm{B}$ cells to produce $\mathrm{IL}-10$ and mediate suppression of antigen-specific CD8 T cells. Cell Mol Immunol. (2019) 17:84355. doi: 10.1038/s41423-019-0324-Z

26. Brosseau C, Durand M, Colas L, Durand E, Foureau A, Cheminant $\mathrm{MA}$, et al. CD9+ regulatory B Cells induce T cell apoptosis via IL10 and are reduced in severe asthmatic patients. Front Immunol. (2018) 9:3034. doi: 10.3389/fimmu.2018.03034 
27. Allman D, Pillai S. Peripheral B cell subsets. Curr Opin Immunol. (2008) 20:149-57. doi: 10.1016/j.coi.2008.03.014

28. Pillai S, Cariappa A. The follicular versus marginal zone B lymphocyte cell fate decision. Nat Rev Immunol. (2009) 9:767-77. doi: 10.1038/nri2656

29. Martin F, Kearney JF. Marginal-zone B cells. Nat Rev Immunol. (2002) 2:32335. doi: 10.1038/nri799

30. Cerutti A, Cols M, Puga I. Marginal zone B cells: virtues of innatelike antibody-producing lymphocytes. Nat Rev Immunol. (2013) 13:11832. doi: $10.1038 /$ nri3383

31. Cuenca M, Romero X, Sintes J, Terhorst C, Engel P. Targeting of Ly9 (CD229) Disrupts marginal zone and B1 B cell homeostasis and antibody responses. $J$ Immunol. (2016) 196:726-37. doi: 10.4049/jimmunol.1501266

32. Cinamon G, Zachariah MA, Lam OM, Foss FW, Cyster JG. Follicular shuttling of marginal zone B cells facilitates antigen transport. Nat Immunol. (2008) 9:54-62. doi: 10.1038/ni1542

33. Rothstein, Thomas L. Cutting edge commentary: two B-1 or not to be one. J Immunol. (2002) 168:4257-61. doi: 10.4049/jimmunol.168.9.4257

34. Martin F, Kearney JF. B1 cells: similarities and differences with other B cell subsets. Curr Opin Immunol. (2001) 13:195201. doi: 10.1016/S0952-7915(00)00204-1

35. Holodick NE, Zeumer L, Rothstein TL, Morel L. Expansion of B-1a cells with germline heavy chain sequence in lupus mice. Front Immunol. (2016) 7:108. doi: 10.3389/fimmu.2016.00108

36. Miles K, Simpson J, Brown S, Cowan G, Gray D, Gray M. Immune tolerance to apoptotic self is mediated primarily by regulatory B1a cells. Front Immunol. (2018) 8:1952. doi: 10.3389/fimmu.2017.01952

37. Gao J, Ma X, Gu W, Fu M, An J, Xing Y, et al. Novel functions of murine B 1 cells: active phagocytic and microbicidal abilities. Eur J Immunol. (2012) 42:982-92. doi: 10.1002/eji.201141519

38. Elliott MR, Ravichandran KS. The dynamics of apoptotic cell clearance. Dev Cell. (2016) 38:147-60. doi: 10.1016/j.devcel.2016.06.029

39. Shin SA, Moon SY, Park D, Park JB, Lee CS. Apoptotic cell clearance in the tumor microenvironment: a potential cancer therapeutic target. Arch Pharm Res. (2019) 42:658-71. doi: 10.1007/s12272-019-01169-2

40. Haas KM, Johnson KL, Phipps JP, Do C. CD22 promotes B-1b cell responses to T Cell-independent type 2 antigens. J Immunol. (2018) 200:167181. doi: 10.4049/jimmunol.1701578

41. Rothstein TL, Griffin DO, Holodick NE, Quach TD, Kaku H. Human B-1 cells take the stage. Ann N Y Acad Sci. (2013) 1285:97. doi: 10.1111/nyas.12137

42. Tangye SG. To B1 or not to B1: that really is still the question!. Blood J Am Soc Hematol. (2013) 121:5109-10. doi: 10.1182/blood-2013-05-500074

43. Satoh M, Takano S, Sogawa K, Noda K, Yoshitomi H, Ishibashi M, et al. Immune-complex level of cofilin-1 in sera is associated with cancer progression and poor prognosis in pancreatic cancer. Cancer Sci. (2017) 108:795-803. doi: 10.1111/cas.13181

44. Newling M, Hoepel W, Vogelpoel LTC, Heineke MH, van Burgsteden JA, Taanman-Kueter EWM, et al. Fc gamma receptor IIa suppresses type I and III interferon production by human myeloid immune cells. Eur J Immunol. (2018) 48:1796-809. doi: 10.1002/eji.201847615

45. Nakamura K, Smyth MJ. Myeloid immunosuppression and immune checkpoints in the tumor microenvironment. Cell Mol immunol. (2019) 17:1-12. doi: 10.1038/s41423-019-0306-1

46. Ammirante M, Luo JL, Grivennikov S, Nedospasov S, Karin M. B-cell-derived lymphotoxin promotes castration-resistant prostate cancer. Nature. (2010) 464:302-5. doi: 10.1038/nature08782

47. Yang C, Lee H, Pal S, Jove V, Deng J, Zhang W, et al. B cells promote tumor progression via STAT3 regulated-angiogenesis. PLoS ONE. (2013) 8:e0064159. doi: 10.1371/journal.pone.0064159

48. Ou Z, Wang Y, Liu L, Li L, Yeh S, Qi L, et al. Tumor microenvironment $B$ cells increase bladder cancer metastasis via modulation of the IL-8/androgen receptor (AR)/MMPs signals. Oncotarget. (2015) 6:26065. doi: 10.18632/oncotarget.4569

49. Lemoine S, Morva A, Youinou P, Jamin C. Human T cells induce their own regulation through activation of B cells. J Autoimmun. (2011) 36:22838. doi: 10.1016/j.jaut.2011.01.005

50. Lee KM, Stott RT, Zhao G, SooHoo J, Xiong W, Lian MM, et al. TGF- $\beta$-producing regulatory $\mathrm{B}$ cells induce regulatory $\mathrm{T}$ cells and promote transplantation tolerance. Eur J Immunol. (2014) 44:172836. doi: 10.1002/eji.201344062

51. Olkhanud PB, Damdinsuren B, Bodogai M, Gress RE, Sen R, Wejksza K, et al. Tumor-evoked regulatory B cells promote breast cancer metastasis by converting resting CD4+ T cells to T-regulatory cells. Cancer Res. (2011) 71:3505-15. doi: 10.1158/0008-5472.CAN-10-4316

52. Bodogai M, Moritoh K, Lee-Chang C, Hollander CM, Sherman-Baust CA, Wersto RP, et al. Immunosuppressive and prometastatic functions of myeloidderived suppressive cells rely upon education from tumor-associated B cells. Cancer Res. (2015) 75:3456-65. doi: 10.1158/0008-5472.CAN-14-3077

53. Neves P, Lampropoulou V, Calderon-Gomez E, Roch T, Stervbo U, Shen $\mathrm{P}$, et al. Signaling via the MyD88 adaptor protein in B cells suppresses protective immunity during Salmonella typhimurium infection. Immunity. (2010) 33:777-90. doi: 10.1016/j.immuni.2010.10.016

54. Fehres CM, van Uden NO, Yeremenko NG, Fernandez L, Franco Salinas G, van Duivenvoorde LM, et al. APRIL induces a novel subset of IgA + regulatory $B$ cells that suppress inflammation via expression of IL-10 and PD-L1. Front Immunol. (2019) 10:1368. doi: 10.3389/fimmu.2019.01368

55. Kemp TJ, Moore JM, Griffith TS. Human B cells express functional TRAIL/Apo-2 ligand after CpG-containing oligodeoxynucleotide stimulation. J Immunol. (2004) 173:892-9. doi: 10.4049/jimmunol.173.2.892

56. Hofmann S, Brüggemann $S$, Beyer $T$, Barth $T$, Deissler $H$, Lotfi $R$, et al. Tumor-infiltrating lymphocytes in breast cancer tissue comprise granzyme B-expressing B cells with cytotoxic potential (127.23). J Immunol. (2012) 188:127-23.

57. Xia Y, Tao H, Hu Y, Chen Q, Chen X, Xia L, et al. IL-2 augments the therapeutic efficacy of adoptively transferred B cells which directly kill tumor cells via the CXCR4/CXCL12 and perforin pathways. Oncotarget. (2016) 7:60461. doi: 10.18632/oncotarget.11124

58. Tabuchi Y, Shimoda M, Kagara N, Naoi Y, Tanei T, Shimomura A, et al. Protective effect of naturally occurring anti-HER2 autoantibodies on breast cancer. Breast Cancer Res Treat. (2016) 157:55-63. doi: 10.1007/s10549-016-3801-4

59. Carmi Y, Spitzer MH, Linde IL, Burt BM, Prestwood TR, Nicola Perlman, et al. Allogeneic IgG combined with dendritic cell stimuli induce antitumour T-cell immunity. Nature. (2015) 521:99-104. doi: 10.1038/nature14424

60. Candolfi M, Curtin JF, Yagiz K, Assi H, Wibowo MK, Alzadeh GE, et al. B cells are critical to T-cell-mediated antitumor immunity induced by a combined immune-stimulatory/conditionally cytotoxic therapy for glioblastoma. Neoplasia. (2011) 13:947. doi: 10.1593/neo.11024

61. DiLillo DJ, Yanaba K, Tedder TF. B cells are required for optimal CD4+ and CD8+ $\mathrm{T}$ cell tumor immunity: therapeutic B cell depletion enhances B16 melanoma growth in mice. J Immunol. (2010) 184:400616. doi: 10.4049/jimmunol.0903009

62. Rossetti RAM, Lorenzi NPC, Yokochi K, Rosa MBSF, Benevides L, Margarido PFR, et al. B lymphocytes can be activated to act as antigen presenting cells to promote anti-tumor responses. PLoS ONE. (2018) 13:e0199034. doi: 10.1371/journal.pone.0199034

63. Berntsson J, Nodin B, Eberhard J, Micke P, Jirström K. Prognostic impact of tumour-infiltrating B cells and plasma cells in colorectal cancer. Int J Cancer. (2016) 139:1129-39. doi: 10.1002/ijc.30138

64. Ho KH, Chang CJ, Huang TW, Shih CM, Liu AJ, Chen PH, et al. Gene landscape and correlation between B-cell infiltration and programmed death ligand 1 expression in lung adenocarcinoma patients from the cancer genome atlas data set. PLoS ONE. (2018) 13:e0208459. doi: 10.1371/journal.pone.0208459

65. Bruno TC, Ebner PJ, Moore BL, Squalls OG, Waugh KA, Eruslanov EB, et al. Antigen-presenting intratumoral B cells affect CD4+ TIL phenotypes in non-small cell lung cancer patients. Cancer Immunol Res. (2017) 5:898907. doi: 10.1158/2326-6066.CIR-17-0075

66. Bruno TC. Evaluating the antitumor role of $\mathrm{B}$ cells in patients with non-small cell lung cancer. J Clin Oncol. (2017) 35:75. doi: 10.1200/JCO.2017.35.7_suppl.75

67. Kroeger DR, Milne K, Nelson BH. Tumor-infiltrating plasma cells are associated with tertiary lymphoid structures, cytolytic T-cell responses, and superior prognosis in ovarian cancer. Clin Cancer Res. (2016) 22:300515. doi: 10.1158/1078-0432.CCR-15-2762 
68. Biswas S, Sengupta S, Roy Chowdhury S, Jana S, Mandal G, Mandal $\mathrm{PK}$, et al. CXCL13-CXCR5 co-expression regulates epithelial to mesenchymal transition of breast cancer cells during lymph node metastasis. Breast Cancer Res Treat. (2014) 143:265-76. doi: 10.1007/s10549-0132811-8

69. Wang X, Cho B, Suzuki K, Xu Y, Green JA, An J, et al. Follicular dendritic cells help establish follicle identity and promote $\mathrm{B}$ cell retention in germinal centers. J Exp Med. (2011) 208:2497-510. doi: 10.1084/jem.20111449

70. Ansel KM, Harris RB, Cyster JG. CXCL13 is required for B1 cell homing, natural antibody production, and body cavity immunity. Immunity. (2002) 16:67-76. doi: 10.1016/S1074-7613(01)00257-6

71. Litsiou E, Semitekolou M, Galani IE, Morianos I, Tsoutsa A, Kara P, et al. CXCL13 production in B cells via Toll-like receptor/lymphotoxin receptor signaling is involved in lymphoid neogenesis in chronic obstructive pulmonary disease. Am J Resp Crit Care Med. (2013) 187:1194-202. doi: 10.1164/rccm.201208-1543OC

72. Sáez de Guinoa J, Barrio L, Mellado M, Carrasco YR. CXCL13/CXCR5 signaling enhances BCR-triggered B-cell activation by shaping cell dynamics. Blood J Am Soc Hematol. (2011) 118:15609. doi: 10.1182/blood-2011-01-332106

73. Mehner C, Hockla A, Miller E, Ran S, Radisky DC, Radisky ES.Mehner C, et al. Tumor cell-produced matrix metalloproteinase 9 (MMP-9) drives malignant progression and metastasis of basal-like triple negative breast cancer. Oncotarget. (2014) 5:2736. doi: 10.18632/oncotarget.1932

74. Roche J. The epithelial-to-mesenchymal transition in cancer. Cancers. (2018) 10:52. doi: 10.3390/cancers10020052

75. Pandruvada SN, Yuvaraj S, Liu X, Sundaram K, Shanmugarajan S, Ries WL, et al. Role of CXC chemokine ligand 13 in oral squamous cell carcinoma associated osteolysis in athymic mice. Int J Cancer. (2010) 126:231929. doi: $10.1002 /$ ijc. 24920

76. Fan L, Zhu Q, Liu L, Zhu C, Huang H, Lu S, et al. CXCL13 is androgenresponsive and involved in androgen induced prostate cancer cell migration and invasion. Oncotarget. (2017) 8:53244. doi: 10.18632/oncotarget.18387

77. Li C, Kang D, Sun X, Liu Y, Wang J, Gao P. The effect of CXC motif chemokine 13 on hepatocellular carcinoma associates with wnt signaling. BioMed Res Int. (2015) 2015:345413. doi: 10.1155/2015/345413

78. Chunsong $\mathrm{H}$, Yuling $\mathrm{H}$, Li $\mathrm{W}$, Jie $\mathrm{X}$, Gang $\mathrm{Z}$, Qiuping $\mathrm{Z}$, et al. CXC chemokine ligand 13 and CC chemokine ligand 19 cooperatively render resistance to apoptosis in $\mathrm{B}$ cell lineage acute and chronic lymphocytic leukemia CD23 + CD5+ B cells. J Immunol. (2006) 177:671322. doi: 10.4049/jimmunol.177.10.6713

79. Hu C, Xiong J, Zhang L, Huang B, Zhang Q, Li Q, et al. PEG10 activation by co-stimulation of CXCR5 and CCR7 essentially contributes to resistance to apoptosis in CD19+CD34+ B cells from patients with b cell lineage acute and chronic lymphocytic leukemia. Cell Mol Immunol. (2004) 1:280-94.
80. Makgoeng SB, Bolanos RS, Jeon CY, Weiss RE, Arah OA, Breen EC, et al. Markers of immune activation and inflammation, and non-Hodgkin lymphoma: a meta-analysis of prospective studies. JNCI Cancer Spectr. (2018) 2:pky082. doi: 10.1093/jncics/pky082

81. Gu-Trantien C, Loi S, Garaud S, Equeter C, Libin M, de Wind A, et al. CD4+ follicular helper $\mathrm{T}$ cell infiltration predicts breast cancer survival. J Clin Invest. (2013) 123:2873-92. doi: 10.1172/JCI67428

82. Razis E, Ioannis K, Kyriaki M, Wirtz RM, Flora Z, George L, et al. Evaluation of the effect of CXCL13 mRNA expression in early breast cancer outcome: a confirmatory study. J Clin Oncol. (2018) 36:e24286. doi: 10.1200/JCO.2018.36.15_suppl.e24286

83. Song IH, Heo SH, Bang WS, Park HS, Park IA, Kim YA, et al. Predictive value of tertiary lymphoid structures assessed by high endothelial venule counts in the neoadjuvant setting of triple-negative breast cancer. Cancer Res Treat. (2017) 49:399. doi: 10.4143/crt.2016.215

84. Rachidi SM, Qin T, Sun S, Zheng WJ, Li Z. Molecular profiling of multiple human cancers defines an inflammatory cancer-associated molecular pattern and uncovers KPNA2 as a uniform poor prognostic cancer marker. PLOS ONE. (2013) 8:e0057911. doi: 10.1371/journal.pone.0057911

85. Li Q, Lao X, Pan Q, Ning N, Yet J, Xu Y, et al. Adoptive transfer of tumor reactive $\mathrm{B}$ cells confers host $\mathrm{T}$-cell immunity and tumor regression. Clin Cancer Res. (2011) 17:4987-95. doi: 10.1158/1078-0432.CCR11-0207

86. Ren H, Zhao S, Li W, Dong H, Zhou M, Cao M, et al. Therapeutic antitumor efficacy of B cells loaded with tumor-derived autophagasomes vaccine (DRibbles). J Immunother. (2014) 37:383. doi: 10.1097/CJI.0000000000000051

87. Bodogai M, Lee Chang C, Wejksza K, Lai J, Merino M, Wersto RP, et al. Anti-CD20 antibody promotes cancer escape via enrichment of tumor-evoked regulatory B cells expressing low levels of CD20 and CD137L. Cancer Res. (2013) 73:2127-38. doi: 10.1158/0008-5472.CAN-12-4184

88. Ma JJ, Jiang L, Tong DY, Ren YN, Sheng MF, Liu HC. CXCL13 inhibition induce the apoptosis of MDA-MB-231 breast cancer cells through blocking CXCR5/ERK signaling pathway. Eur Rev Med Pharmacol Sci. (2018) 22:875562. doi: 10.26355/eurrev_201812_16641

Conflict of Interest: The authors declare that the research was conducted in the absence of any commercial or financial relationships that could be construed as a potential conflict of interest.

Copyright (C) 2020 Rubio, Porter and Zhong. This is an open-access article distributed under the terms of the Creative Commons Attribution License (CC BY). The use, distribution or reproduction in other forums is permitted, provided the original author(s) and the copyright owner(s) are credited and that the original publication in this journal is cited, in accordance with accepted academic practice. No use, distribution or reproduction is permitted which does not comply with these terms. 